IRSH 50 (2005), Supplement, pp. I 23-I 48 DOI: I0. I0 I7/So020859005Ir50s I 39

(C) 2005 Internationaal Instituut voor Sociale Geschiedenis

\title{
Homogamy in a Society Orientated towards Stability: A Micro-study of a South Tyrolean Market Town, I $700-1900$
}

\author{
MARGARETH LANZINGER
}

Summary: In the German-speaking areas of Habsburg Tyrol, investigated here, the aim of regional politicians and communal representatives was to perpetuate the status quo of ownership and social structure. The most important instruments for realizing that aim were policies on marriage and settlement. In addition, inheritance was based on male primogeniture, which supported a tendency for the sizes of property to remain stable. Throughout the region there was an attitude generally hostile to industry, so when, in the nineteenth century, branches of the crafts producing wares for translocal markets became unprofitable, industrialization offered no alternative. In those circumstances, marriage can be regarded as practically a privilege. Does that relativize or augment the consideration of homogamy? It seems both cases are possible: slight tendencies to socially downward marriage support the first assumption; the second appears to be supported by the various shifts in marriage habits - reactions to changed social positions - among the most important groups over the course of the nineteenth century.

The choice of partner affected not only the bride and groom but should be seen as part of a complex network of relationships. Differing interests and expectations of the families of origin or close relatives, as much as of the wider society, always play a role, and can influence the decision as to who might be considered a suitable bride or groom. Social status is an important factor in forming the cultural patterns that define the criteria and parameters determining who was considered the "right" groom and the "right" bride. I Great significance is generally ascribed to economic considerations. These comprise not only property, inheritance, dowry, and so on, but also involve labour power, relevant professional training, and work experience or socialization. Finally, a marriage can provide a foundation for new local or translocal alliances and networks, or it can

I. See for example Pat Hudson and Steven King, "Marriage in Two English Textile Manufacturing Townships in the Eighteenth Century”, in Christophe Duhamelle and Jürgen Schlumbohm (eds), Eheschließungen im Europa des I8. und I9. Jabrbunderts. Muster und Strategien (Göttingen, 2003), pp. I 57- I 88. 
further develop and stabilize existing ones. Increasingly in recent years, greater attention and significance have been given to emotional components: economic calculations do not exclude the existence of emotional ties, and ideally both coincide. In particular, familiarity, acquaintance with the same social milieu with common experiences in childhood and youth, "emotional security" based on kinship, and socio-economic or neighbourly relationships have proved in some studies to be important motives and a basis for subsequent marriage. ${ }^{2}$

The choice of partner was not independent of a broader social context: in the specific region investigated here, which can be roughly described geographically as German-speaking areas of the eastern part of the Habsburg Tyrol, ${ }^{3}$ the legal framework, ideas of political authority and its influence, and transformations in those ideas all affected the frequency of marriage, and sometimes quite significantly. The objective of the communal representatives and a substantial proportion of regional politicians was to perpetuate the status quo of ownership and social structures. The most important instruments for realizing that were, on one hand, marriage restrictions - the possibility of marriage in the region tended to be linked to property - and on the other hand, restrictive settlement policies, which primarily regulated and controlled the influx of men from outside and thereby the possibility of anyone's marrying into the community. It can be presumed that these restrictions were more rigidly enforced in the economically more attractive markets and in cities more than in villages.

As well as the regulation of migration and settlement, conditions of acceptance into various crafts or trades and the concomitant fees could delay or even prevent marriage, ${ }^{4}$ or suggest the expediency of wedding a local citizen's daughter or a master's daughter or perhaps his widow. Inheritance laws and practice created different starting conditions and so different opportunities for marriage. 5 Framework conditions were created

2. Ibid.; Heide Wunder et al., "Ehepaare, Eheverläufe und Lebenslauf in Leipzig I580-1730. Bericht über ein Forschungsprojekt", in Katharina Midell (ed.), Ehe, Alltag, Politik. Studien zu Franengeschichte und Geschlechterverhältnissen der frühen Neuzeit bis zur Gegenwart (Leipzig, I993), pp. 13-32, 20.

3. At that time Tyrol included - with certain territorial alterations - North and East Tyrol, which are part of present-day Austria, and South Tyrol and Trentino in Italy. The administrative unit also included Vorarlberg, located westward in the direction of Switzerland, and which today is part of Austria.

4. See Anne-Lise Head-König, "Les politiques étatiques coercitives et leur influence sur la formation du mariage en Suisse au XVIIIe siècle", in Duhamelle and Schlumbohm, Eheschließungen im Europa, pp. I89-2 I4.

5. There were other restrictions that will not be discussed in further detail here. The marriage prohibitions vehemently propagated by the Catholic Church throughout the nineteenth century also hampered marriage between persons of different confessions or religions and between persons related by blood or marriage - far beyond the marriage restrictions provided for in the 
which affected who was permitted to marry at all. Choice of partner too was strongly "economicized" in this way.

The range of general and regional factors delineated here, which flowed into the realization of marriage plans and could either foster, delay or prevent them, is to be examined in detail in the following section dealing with the specific location of this study, and this socio-political context provides a basis for the evaluations in the second part of the article. The focus here is first on the significance of social homogamy, and then on the extent to which the internationally standardized classification system HISCLASS, here tested, is congruent with or deviates from local criteria for outlining the social structure in that location.

Despite some specific exceptions, marriage can here be regarded practically as a privilege - does that relativize or augment the consideration of homogamy? In this context several other questions need to be raised: How can social equality between bride and groom be defined and how can it be operationalized? Do the criteria for assessing social status change when observed over 200 years, from I 700 to I 900 ? In what follows, I shall be able to address only a few points of these fundamental questions. I will concentrate on the socio-political, socio-economic, and sociocultural circumstances of partner selection based on a micro-study focusing on marriage in local and family contexts. The setting is Innichen/San Candido, today a market town in South Tyrol/northern Italy; and the period under review is 1700 to $1900 .{ }^{6}$ Innichen's character has been shaped by crafts, trade, and agriculture, and in a regional comparison it evinces an above-average commercial density: in I 790 every tenth resident in the town was a craftsman or tradesman. ${ }^{7}$

\section{SOCIO-POLITICAL, SOCIO-ECONOMIC, AND SOCIO-CULTURAL CONTEXTS}

Briefly, communal politics in those two centuries was characterized by the endeavour to maintain existing social structures, ${ }^{8}$ a guiding principle

I 8 I I Civil Code (Allgemeines Bürgerliches Gesetzbuch, ABGB). The bishops responsible for the diocese of Brixen, the region being studied here, were intent on maintaining the Catholic unity of the country and attempted to block interconfessional marriages. In relation to marriages between relatives and in-laws, canon law, which until I91 7 allowed dispensation up to the fourth degree, continued to be followed, so the reduction in the statutory dispensation to just the second degree, as specified in the ABGB, was ignored.

6. See Margareth Lanzinger, Das gesicherte Erbe. Heirat in lokalen und familialen Kontexten, Innichen 1700-1900 (Vienna [etc.], 2003).

7. See Rosa Lanzinger, "Gewerbetopographie des Landesgerichtes Sillian im Zeitraum von 1720 bis I 860" (Ph.D., Innsbruck, I980), pp. $47 \mathrm{ff}$.

8. See Jon Mathieu's argument for paying greater consideration to the political aspects of the organization of society: Jon Mathieu, "From Ecotypes to Sociotypes: Peasant Household and 
carried forward by a broad middle class of mainly craftsmen and large farmers, and by the local elite. Prevailing with rigidity and through mechanisms of exclusion, this principle was supported at the same time by measures of social integration. ${ }^{9}$

Until the mid-nineteenth century, communal representatives controlled and regulated influx and settlement through the granting of the right of communal citizenship or the temporary acceptance of residents as socalled Inwohner (roughly speaking, "dwellers"). The community decided in each individual case who was permitted to settle in the town as a citizen and who could then marry. A relatively high citizenship fee had to be paid upon acceptance. As case reconstructions have shown, the community made the settlement of men from other places dependent, with very few exceptions, on their economic potential, professional abilities, and prospects in the town. In many cases, acceptance as a citizen and marriage took place within a very short period of time, or acceptance was preceded by the purchase of a house, which indicates that a pre-condition for acceptance, frequently through marriage, was integration into local social fields.

The communal right of citizenship mainly regulated the settlement of men and to that extent the gender-specific differences in marriage patterns in terms of local endogamy and exogamy are certainly to be viewed in the same context. By contrast, women could marry into the town without having to surmount comparable hurdles, not least financial ones. What is conspicuous - and under the framework conditions described can perhaps be regarded as a kind of compensation - was the increasing proportion of couples in which the man was from Innichen and the woman from a different town. In the second half of the nineteenth century that was true in 57.4 per cent of the marriages in the sample described in the next section. ${ }^{10}$ The Inwobner were at an intermediate stage. They were accepted for one year at a time and had to pay an annual fee to the community for residence.

Property was considered a prerequisite for marriage, a custom given a legal basis in 1820 with the introduction of the political marriage consensus. Every couple intending to marry had to bring the parish priest confirmation from the community that they were in possession of sufficient property to support a family - otherwise they could not be

State-Building in the Alps, Sixteenth-Nineteenth Centuries", The History of the Family, s (2000), pp. 55-74.

9. Jobs providing community services - such as the nightwatchman - were assigned to economically weaker people. The allocation of assistance from the communal funds for the poor or wood for the needy, which was linked to the status of communal citizenship, can also be interpreted in this sense.

I0. The high proportion of women who married into the community resulted in gaps in the documented personal data, especially in the eighteenth century; this also extended to the occupations of the fathers. 
married. The political marriage consensus was primarily conceived as a measure against pauperism in cities like Vienna and Prague, although it was hardly possible to administer it there, and it met with rejection in many parts of the Habsburg monarchy, being treated as a purely formal act. However, in broad sections of regional and communal politics in German-speaking Tyrol it was readily accepted and applied more rigidly than originally intended, as is evident from appeals. It was abolished throughout the monarchy in I 868 - except in Salzburg, where it remained in effect until I 883, and in Tyrol, where it remained in effect until I92 I (in South Tyrol until 1923). ${ }^{\text {II }}$ In Innichen, the limitation in the marriage consensus to "servants, apprentices, and day-labourers", who received alms, pursued no employment and led an unsteady life, was ignored, and the decision-making competence remained with the community rather than being transferred to the district authorities, as is evident from the minutes of the meetings of the community council.

This "restrictive policy" is evident in a number of other areas, which in general resulted in an astonishing stability: there was barely any change at all in the number of residents between the mid-eighteenth century and the mid-nineteenth century - and that at a time when the population doubled or even tripled in other places. In I75 I there were 1,090 inhabitants in the town and on the mountain put together; in I 850 there were I, I 20, of whom 927 lived in the town. ${ }^{12}$ The number of houses also remained constant, although some were divided into two or three. In 1799 there was a report in conjunction with a new assessment of the well tax claiming that 40 years had passed since the last tariff regulation and that there was one house more since then. ${ }^{13}$ The number of houses mentioned there remained constant at I 28 for several more decades (see Figure I). House-building activity is first documented again during the period of railway construction after i 870 .

This supports the concomitant tendency for the size of property to remain stable due to the law of male primogeniture, with the undivided

I I. See Elisabeth Mantl, "Legal Restrictions on Marriage: Marriage and Inequality in the Austrian Tyrol during the Nineteenth Century", The History of the Family, 4 (1999), pp. I $85-$ 207; Elisabeth Mantl, Heirat als Privileg. Obrigkeitliche Heiratsbeschränkungen in Tirol und Vorarlberg I820-1920 (Vienna [etc.], 1997).

I2. For 175 I see Hans Kramer, "Beiträge zur Geschichte des Landgerichtes Sillian in Osttirol von ungefähr I750 bis I850", Carinthia I, I 52 (1962), pp. 27-59, 30; for I 850 see Stiftsarchiv [hereafter, STA] Innichen, Familienbuch I 829 - Einwohner vom Markte Innichen und auf dem Innichberge [hereafter, Familienbuch I 829], Appendix.

I3. See Tiroler Landesarchiv Innsbruck [hereafter, TLA], Verfachbuch Innichen [hereafter, VBI] I799, fo. I 234 r. There is documentation relating to a conflict involving the building of this house at the end of the eighteenth century between the community and the prospective builder, a new resident; TLA, VBI I777, fo. 330r; VBI I78 I, fos 880r-88 Ir. See also Margareth Lanzinger, "The House as Demographic Factor? Elements of a Marriage Pattern under the Auspices of Hindrance Policies", Historical Social Research, 28 (2003), pp. 58-75, 7I ff. 


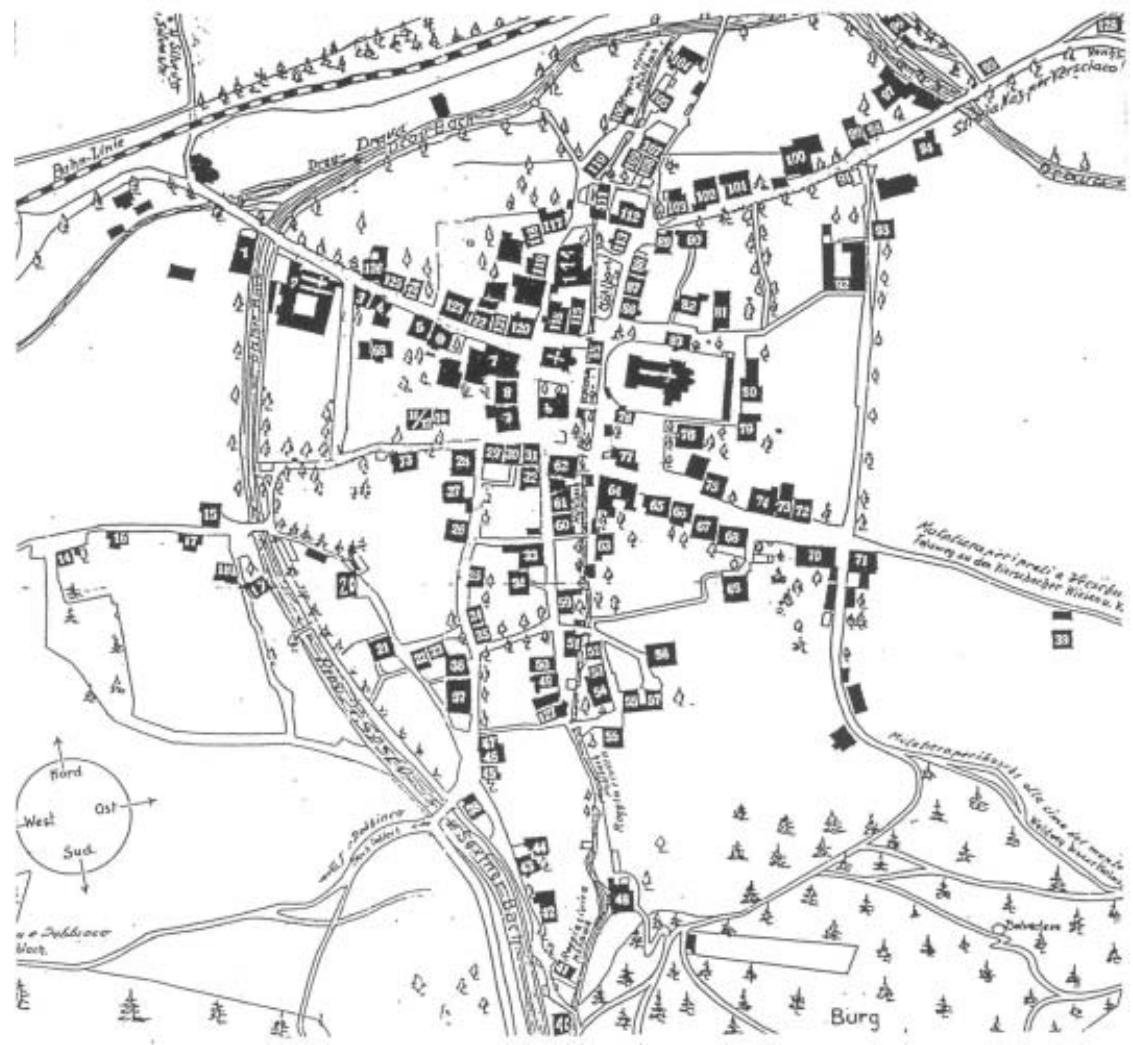

Figure I. Map of Innichen in the nineteenth century.

transfer of property on succession. ${ }^{14}$ Whereas in the eighteenth century a large degree of flexibility can be noted in the application of that model of property transfer, with younger brothers and even sisters frequently taking over property, a change was evident in the nineteenth century in the

I4. The transition from the dominance of medium-sized and larger farms in the eastern Alpine region to the dominance of smaller farms in the western region runs right through what is today North Tyrol and South Tyrol. Whereas at the beginning of the nineteenth century the proportion of medium-sized and larger farms ( 10 hectares or more) ranged from over 40 per cent to 60 per cent in the eastern part of Tyrol (similar to the districts of Salzburg and Carinthia) including the district of Lienz, with 58 per cent, to which Innichen belongs - the proportion of medium-sized and larger farms in the west - similar to Vorarlberg and Italian-speaking Trentino - was between just I per cent and 5 per cent. See Ergebnisse der landwirtschaftlichen Betriebszählung vom 3. Juni 1902 in den im Reichsrate vertretenen Königreichen und Ländern, bearbeitet von dem Bureau der k.k. statistischen Zentralkommision (Vienna, I909), cited from Jon Mathieu, Geschichte der Alpen I500-1900. Umwelt, Entwicklung, Gesellschaft (Vienna [etc.], I998), Table A.5, pp. 2 I 4 ff. 
direction of decreasing flexibility: in terms of property transfer within the family, in the nineteenth century the eldest son inherited significantly more often than in the eighteenth century. ${ }^{15}$ Instead of a certain dynamic the eldest son bought a different house, married an heiress, settled elsewhere - which allowed for more opportunities for younger siblings of either gender, there developed a relatively rigid and immobile system which more closely followed the normative model. At the same time, that model was more strongly orientated towards the male line. The thesis is that the property succession of the first-born male grew to be a kind of ideology in the course of the nineteenth century, becoming increasingly dominant and affecting actual inheritance practice. ${ }^{16}$

These manifestations of increasing rigidity can be explained by socioeconomic changes, because overall changes in society in the nineteenth century did not stop at the threshold of the town. Due to changing markets and industrial competition, branches of crafts such as glove-making or linen weaving, producing particularly for translocal markets, became unprofitable; and new transport possibilities caused the carrying trade to dwindle. In the eighteenth century many people went to Vienna from Innichen as journeyman craftsmen - a distance of over $500 \mathrm{~km}$ - or settled somewhere in the Habsburg monarchy, in southern Germany or northern Italy. With industrialization and the end of journeyman wanderings, this reason for migration largely vanished. An attitude generally hostile to industry was predominant in the region of Innichen itself, so industrialization did not offer any alternatives.

The high proportion of unmarried people and the late age at first

I 5 . Cf. the evaluation of a sample to compare the link between marriage and property in the sibling context for the years 1730-1750 and I 830-1850 in Lanzinger, Das gesicherte Erbe, pp. $242 \mathrm{ff}$.

r6. Michaela Hohkamp and Jürgen Schlumbohm come to similar conclusions on this question. See Michaela Hohkamp, "Wer will erben? Überlegungen zur Erbpraxis in geschlechtsspezifischer Perspektive in der Herrschaft Triberg von I654-1 806”, in Jan Peters (ed.), Gutsherrschaft als soziales Modell. Vergleichende Betrachtungen zur Funktionsweise frühneuzeitlicher Agrargesellschaften (Munich, 1995), pp. 327-34I, 338; Jürgen Schlumbohm, Lebensläufe, Familien, Höfe. Die Bauern und Hewerleute des Osnabrückischen Kirchspiels Belm in proto-industrieller Zeit, I650-I860 (Göttingen, I994), p. 39I. For a different model see Marie-Pierre Arrizabalaga, "The Stem Family in the French Basque Country: Sare in the Nineteenth Century", Journal of Family History, 22 (1997), pp. 50-69, 54 ff., and also her article in this volume, pp. 93-I 22; Margareth Lanzinger, "Towards Predominating Primogeniture: Changes in the Inheritance Practices, Innichen/San Candido 1730-1930", in Hannes Grandits and Patrick Heady (eds), Distinct Inheritances: Property, Family and Community in a Changing Europe (Münster, 2003), pp. I25-I44. A phenomenon in the convention of naming can also be seen parallel to this in the form of a stronger concentration on the father-son line: the most conspicuous change in the second half of the nineteenth century is the significant increase in naming children after paternal grandparents, and a decrease in naming them after godparents. A gender-specific analysis showed that this change was primarily related to the naming of boys. See Margareth Lanzinger, "Namenkultur - mikrohistorisch und auch quantitativ", Historische Anthropologie, 10 (2002), Pp. II - I 24, I2I ff. 
marriage can be taken as indicators of the deterioration of the overall situation in consequence of the circumstances briefly outlined here. According to the census for 1880 , in the district of Lienz, to which Innichen belonged, almost half the men and women aged $4 \mathrm{I}$ to $50(48.3 \mathrm{per}$ cent and 50.I per cent respectively) and aged 5 I to 60 (43.7 per cent and 49.8 per cent respectively) were unmarried. ${ }^{17}$ The average age at first marriage was comparatively high and rose in the course of the period investigated: from 28.5 years for women and 30 years for men in the second half of the eighteenth century to 3 I.5 years for women and 34.5 years for men respectively in the second half of the nineteenth century.

In the combination of these factors, marriage assumed a key role in several respects: marriage constraints were intended to hinder as far as possible the reproduction of those who were economically weaker and so keep as low as possible the number receiving support from the local fund for the poor. The number of marriages dropped in the period following the introduction of the marriage consensus in the 1820 s and again around the mid-nineteenth century (Figure 2), which was a restorative phase on the whole, both from a political perspective regionally and locally, when, among other measures, the application of the marriage consensus was intensified. The end of the communal right of citizenship following the model of the ancien régime in the mid-nineteenth century did not result in greater openness. The community laws newly passed and altered several times until the end of the nineteenth century and intended to regulate the pre-conditions for settlement meant that Innichen increasingly closed itself off from the outside world. It became even more difficult and increasingly rare for men from elsewhere to marry into the community. ${ }^{18}$

According to the picture so far sketched here, Innichen was a comparatively restrictive and strongly self-regulated society that did not seem to leave much scope for negotiation. However, a liber status animarum, which documents the local populace for the I830s and the I 840 , also lists "inmates", a term used to describe couples and families without property according to the criteria of house ownership. ${ }^{19}$ So, was the marriage-consensus policy not so very rigorous after all? The reconstruction of the lives of married couples who did not own a house and lived as inmates in the 1830 s and I 840 demonstrated a range of causes showing that their situation was anything from a temporary solution while awaiting inheritance to the result of loss of property, for instance due to bankruptcy; and in a few cases, despite the marriage-consensus policy, a marriage between persons without property. In I 849 , for example, in a 


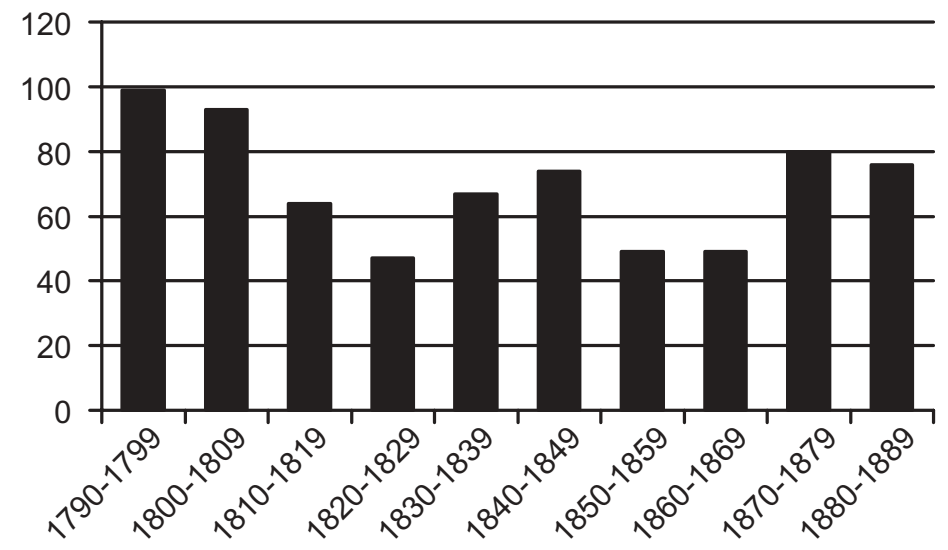

Figure 2. Number of marriages in the parish of Innichen, 1790-1889.

Source: STA Innichen, Liber Conjugatorum, Tomus II, I76I-I784; Tomus IIIa, I784-I882; Trauungsbuch, Bd. 4, I845-1927; Liber Baptizatorum, Copulatorum, Mortuorum vom Innichberg, I786-I807. The figures for the individual decades are: I790-I799: 99; I 800-1809:

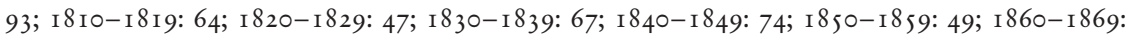
49; I 870-I 879: 80; I 880-I 889: 76 .

total of I54 households, there were 8 married couples, 8 parents with children, and ro couples with children living in the town as inmates, of which 3 families and 3 couples did not fulfil the property criterion, neither at the time of marriage nor in realistic prospect.

Two patterns are evident in those cases, which are probably the reason why the couples in question nevertheless received permission to marry: the existence of illegitimate children, or that the women were past childbearing age, so that, in other words, the motivation was towards moral virtue on the one hand, and on the other the calculation that the poor economic situation would not be continued into another generation, so preventing proletarianization. ${ }^{20}$ The men are listed with the following occupations: butcher, weaver, fruit and crockery peddler, day-labourer, and a pair of former servants from East Tyrol, who were charged with the care of the hospice in return for their lodging. ${ }^{21}$

If we presume that social profiles are to be conceptualized in a very complex way, then I see the attempt undertaken here to pursue this

20. See Hans Henrik Bull in this volume, pp. 43-63. In Innichen one illegitimate child was obviously not "sufficient" to apply pressure for permission to marry; either there were already two, or the second was on the way. The illegitimacy rates are comparatively low here, between o per cent and 6 per cent per year in Innichen in the nineteenth century.

21. See Lanzinger, Das gesicherte Erbe, pp. 2 I4 ff. 
through an internationally standardized classification as a test case. Classification and the formation of categories are necessarily schematizing processes. The broader the area in which the classification is to be applied, the more removed is the classification from the actual social contexts of a certain time, a certain region, which means that according to its methodological conception it contradicts in fact a micro-historical procedure. However, it can be interesting to analyse the pivotal points where shifts and deviations can be noted between the results achieved with HISCLASS, as a "macro-model" coming in from outside, and a microhistorical approach which works with criteria derived from an actual local society. For this reason, this text is intended, to a certain extent, to be a contribution to an ongoing discussion that should, in my opinion, stimulate an important theoretical, methodological debate on the relationship between methods and results.

This must be qualified by noting that a number of aspects of real and symbolic capital, such as property and income, family prestige, and dignity of office or profession, cannot be taken into consideration in this evaluation because of the amount and complexity of data required; all the same, they contribute substantially to people's social positioning, which is composed of multiple factors.

\section{THE DATASET}

The evaluations are based primarily on information from the Familienbuch - "Book of Families beginning in 1700" - from the Innichen monastery archive. ${ }^{22}$ This is a family reconstruction undertaken by a canon of the monastery in I893-I894, and took nearly a year to complete. ${ }^{23}$ The Familienbuch begins with the first marriage in 1700 and covers the period until the beginning of the twentieth century with subsequent additions. All married couples are listed alphabetically in chronological order according to the first letter of the husband's surname, with children's names added from baptismal registers.

In terms of exact data, the density of information is considerably greater for husbands than for wives. Missing data for local residents can be supplied in most cases from the relevant church registers; for the I 830 and I 840 S gaps in information can be filled using data from the liber status

22. STA Innichen, Familienbuch angefangen vom Jahre 1700 [hereafter, Familienbuch I 700 ]. 23. The origins of this Familienbuch thus belongs to an earlier period than the Ortssippenbücher ["Local Kinship Books"], a comparable type of source, which was drawn up in the I930s in Germany and has a more reprehensible history. See John Knodel, Demographic Behavior in the Past: A Study of Fourteen German Village Populations in the Eighteenth and Nineteenth Centuries (Cambridge, I988); John Knodel, "Ortssippenbücher als Quelle für die Historische Demographie”, Geschichte und Gesellschaft, I (1975), pp. 288-324. 
animarum mentioned above; information on craftsmen and tradesmen has been obtained from the thesis by Hermann Rogger. ${ }^{24}$

On the basis of this Familienbuch and the supplementary sources mentioned, I prepared a kleio database in the course of my thesis which largely follows the structure of the source. ${ }^{25}$ For the market town, all families were included in the database, along with their branches, which had lived in Innichen over three generations in at least one line of descent. This enabled sources of error to be eliminated. For example, many women from Innichen married in the town but never lived there after their wedding, so that they and their husbands are registered as childless couples. The families from the Innichen mountain were all included, in order to provide a solid foundation for examining mountain-farming marriage circles and inheritance practice. In addition, property transactions and information on the whereabouts or activities of persons were included in the database from the Verfachbuch registers. ${ }^{26}$

The following evaluations include only first marriages. This is based on the assumption that first marriages are more important for social positioning than later marriages, which follow a different logic. Only those couples are taken into consideration for whom information is available about the occupation of the bride's father as well as the groom's. All occupations are classified using HISCO and then grouped using HISCLASS. ${ }^{27}$

\section{HOMOGAMY IN RELATION TO THE FAMILIES OF ORIGIN}

In the light of the regulated influx and marriage restrictions, and the inheritance practice of intact transfer, the market town is to be regarded in some areas as a quasi-"closed" and exclusive society with a dominant middle class of property owners. Marriage circles concentrated around these middle segments of craftsmen, tradesmen and farmers. The internal

24. Hermann Rogger, "Handwerker und Gewerbetreibende in Innichen seit dem 17. Jahrhundert. Ein Beitrag zur Familien- und allgemeinen Sozialgeschichte dieses Hochpustertaler Marktfleckens" (Ph.D, Innsbruck, I986).

25. Margareth Lanzinger, "Heirat in lokalen und familialen Kontexten. Innichen 1700-1900" (Ph.D., Vienna, 1999). The structure of the database is similar to the model in Peter Becker and Thomas Werner, Kleio. Ein Tutorial (St Katharinen, I991); see also Manfred Thaller, Kleio: A Database System (St Katharinen, 1993).

26. The Verfachbücher, which are unique to Tyrol, contain various types of contracts and agreements that were concluded in court as an instance of civil law, as well as purchase and transfer agreements. In the I940s Josef Oberforcher prepared registers for, inter alia, the Verfachbuch Innichen (Bezirksheimatmuseum [hereafter, BHM] Lienz, Oberforcher Regesten [hereafter, OR]).

27. M.H.D. van Leeuwen and I. Maas, "HISCLASS", paper presented at the sth European Social Science History Conference (Berlin, 24-27 March 2004); I. Maas and M.H.D. van Leeuwen, "SPSS recode job from HISCO into HISCLASS", May 2004. 
distribution, however, may have shifted in some places over the course of time due to the socio-political changes outlined above. In order to be able to focus on these kinds of shift, the evaluation of the period from i 700 to I 900 is subdivided into fifty-year sections (Table I). ${ }^{28}$

As is to be expected, marriage circles condense into three groups: skilled workers, farmers, and lower-skilled workers, who comprise between 85 per cent and just over 97 per cent in the individual time periods. From the perspective of the groom (row), the homogamy rate of sons of skilled workers dropped between 1700 and I 850 from 57.6 per cent to 25.5 per cent, and rose again in the second half of the nineteenth century to $4 \mathrm{I} .7 \mathrm{per}$ cent. With the exception of the first half of the nineteenth century, the separate occupational field of skilled workers is the most important one for the choice of partner. Among the sons of farmers one notes an increase from 68 per cent to 78.3 per cent in the eighteenth century and a decrease to $7 \mathrm{I} .4$ per cent between I 800 and I 849 , followed by a renewed increase to 80.5 per cent, whereby marriages with daughters from the same occupational origins consistently reached the highest rates overall.

In comparison with skilled workers and farmers, the sons of lowerskilled workers consistently married less commonly within their own group - to a maximum of 27.3 per cent of cases (1700-1749) and a minimum of I 3.6 per cent (I850-I899). Instead, they tended to marry with an alternating preference or to the same extent in the first half of the nineteenth century - daughters of skilled workers (with 54.5 per cent most frequently in the first half of the eighteenth century) or farmers (with 44.4 per cent most frequently in the second half of the eighteenth century), evincing a clear tendency to marry upward. This can be interpreted as social mobility, but it could also indicate a need to "reconsider how we have categorized individual groups".

Whereas for the first half of the eighteenth century the findings in terms of marriage circles from the perspective of men and women are nearly identical (daughters of skilled workers married sons of skilled workers in 6I.3 per cent of cases, daughters of farmers married sons of farmers in 68 per cent of cases, and daughters of lower-skilled workers married sons of skilled workers in 60 per cent of cases), differences emerged over the course of time, particularly in the relationship between farming origins and craft origins.

Homogamy is less characteristic of the farmer group: in the individual fifty-year segments between 1750 and I 899 farmers' daughters less often married farmers' sons than vice versa by respectively 23.8 per cent, I 3 per cent, and I 3.2 per cent. Consistently just over 20 per cent of farmers' daughters married sons of skilled workers. In comparison with craftsmen's

28. For the first half of the eighteenth century the information in the database is less dense, due to the mode of inclusion described above - some distortions are therefore possible. 
Table I. Occupation of father of the groom (row) by that of father of the bride (column), first marriage of groom, according to HISCLASS

\begin{tabular}{|c|c|c|c|c|c|c|c|}
\hline \multicolumn{8}{|l|}{ Father of the bride } \\
\hline $\begin{array}{l}\text { Count } \\
\text { Row \% } \\
\text { Column \% } \\
\text { Total \% }\end{array}$ & $1+2^{*}$ & $3+4+5$ & $6+7$ & 8 & 9 & 11 & $\begin{array}{l}\text { Row } \\
\text { Total }\end{array}$ \\
\hline \multicolumn{8}{|l|}{$\begin{array}{l}1700-1749 \\
\text { Father of the groom }\end{array}$} \\
\hline $\begin{array}{l}\text { Lower managers } \\
\text { and professionals, } \\
\text { clerical and sales } \\
(3+4+5)\end{array}$ & & $\begin{array}{r}1 \\
50.0 \\
33.3 \\
1.4\end{array}$ & $\begin{array}{r}1 \\
50.0 \\
3.2 \\
1.4\end{array}$ & & & & $\begin{array}{l}2 \\
2.8\end{array}$ \\
\hline Skilled workers $(6+7)$ & $\begin{array}{r}1 \\
3.0 \\
50.0 \\
1.4\end{array}$ & $\begin{array}{r}1 \\
3.0 \\
33.3 \\
1.4\end{array}$ & $\begin{array}{l}19 \\
57.6 \\
61.3 \\
26.8\end{array}$ & $\begin{array}{r}6 \\
18.2 \\
24.0 \\
8.5\end{array}$ & $\begin{array}{r}6 \\
18.2 \\
60.0 \\
8.5\end{array}$ & & $\begin{array}{l}33 \\
46.5\end{array}$ \\
\hline $\begin{array}{l}\text { Farmers and fishermen } \\
(8)\end{array}$ & $\begin{array}{r}1 \\
4.0 \\
50.0 \\
1.4\end{array}$ & $\begin{array}{r}1 \\
4.0 \\
33.3 \\
1.4\end{array}$ & $\begin{array}{r}5 \\
20.0 \\
16.1 \\
7.0\end{array}$ & $\begin{array}{l}17 \\
68.0 \\
68.0 \\
23.9\end{array}$ & $\begin{array}{r}1 \\
4.0 \\
10.0 \\
1.4\end{array}$ & & $\begin{array}{l}25 \\
35.2\end{array}$ \\
\hline $\begin{array}{l}\text { Lower-skilled workers } \\
\text { (9) }\end{array}$ & & & $\begin{array}{r}6 \\
54.5 \\
19.4 \\
8.5\end{array}$ & $\begin{array}{r}2 \\
18.2 \\
8.0 \\
2.8\end{array}$ & $\begin{array}{r}3 \\
27.3 \\
30.0 \\
4.2\end{array}$ & & $\begin{array}{l}11 \\
15.5\end{array}$ \\
\hline $\begin{array}{l}\text { Column } \\
\text { Total }\end{array}$ & $\begin{array}{l}2 \\
2.8\end{array}$ & $\begin{array}{l}3 \\
4.2\end{array}$ & $\begin{array}{l}31 \\
43.7\end{array}$ & $\begin{array}{l}25 \\
35.2\end{array}$ & $\begin{array}{l}10 \\
14.1\end{array}$ & & $\begin{array}{c}71 \\
100.0\end{array}$ \\
\hline $1750-1799$ & $1+2$ & $3+4+5$ & $6+7$ & 8 & 9 & 11 & $\begin{array}{l}\text { Row } \\
\text { Total }\end{array}$ \\
\hline $\begin{array}{l}\text { Higher managers } \\
\text { and professionals }(1+2)\end{array}$ & $\begin{array}{r}1 \\
25.0 \\
20.0 \\
0.7\end{array}$ & $\begin{array}{r}1 \\
25.0 \\
10.0 \\
0.7\end{array}$ & & & $\begin{array}{r}2 \\
50.0 \\
10.0 \\
1.4\end{array}$ & & $\begin{array}{l}4 \\
2.9\end{array}$ \\
\hline $\begin{array}{l}\text { Lower managers } \\
\text { and professionals, }\end{array}$ & $\begin{array}{c}2 \\
15.4\end{array}$ & $\begin{array}{c}3 \\
23.1\end{array}$ & $\begin{array}{c}4 \\
30.8\end{array}$ & $\begin{array}{l}1 \\
7.7\end{array}$ & $\begin{array}{c}3 \\
23.1\end{array}$ & & 13 \\
\hline clerical and sales & $\begin{array}{r}40.0 \\
1.4\end{array}$ & 30.0 & 10.8 & 1.5 & 15.0 & & 9.3 \\
\hline $\begin{array}{l}(3+4+5) \\
\text { Skilled workers }(6+7)\end{array}$ & $\begin{array}{l}1.4 \\
2\end{array}$ & $\begin{array}{l}2.1 \\
3\end{array}$ & $\begin{array}{l}2.9 \\
20\end{array}$ & $\begin{array}{l}0.7 \\
16\end{array}$ & $\begin{array}{l}2.1 \\
8\end{array}$ & & \\
\hline & $\begin{array}{r}4.1 \\
40.0 \\
1.4\end{array}$ & $\begin{array}{r}6.1 \\
30.0 \\
2.1\end{array}$ & $\begin{array}{l}40.8 \\
54.1 \\
14.3\end{array}$ & $\begin{array}{l}32.7 \\
24.2 \\
11.4\end{array}$ & $\begin{array}{r}16.3 \\
40.0 \\
5.7\end{array}$ & & $\begin{array}{l}49 \\
35.0\end{array}$ \\
\hline $\begin{array}{l}\text { Farmers and fishermen } \\
(8)\end{array}$ & & $\begin{array}{r}1 \\
2.2 \\
10.0 \\
0.7\end{array}$ & \begin{tabular}{r}
\multicolumn{1}{c}{4} \\
8.7 \\
10.8 \\
2.9
\end{tabular} & $\begin{array}{l}36 \\
78.3 \\
54.5 \\
25.7\end{array}$ & $\begin{array}{r}3 \\
6.5 \\
15.0 \\
2.1\end{array}$ & $\begin{array}{r}2 \\
4.3 \\
100.0 \\
1.4\end{array}$ & $\begin{array}{l}46 \\
32.9\end{array}$ \\
\hline
\end{tabular}


Table I. Continued

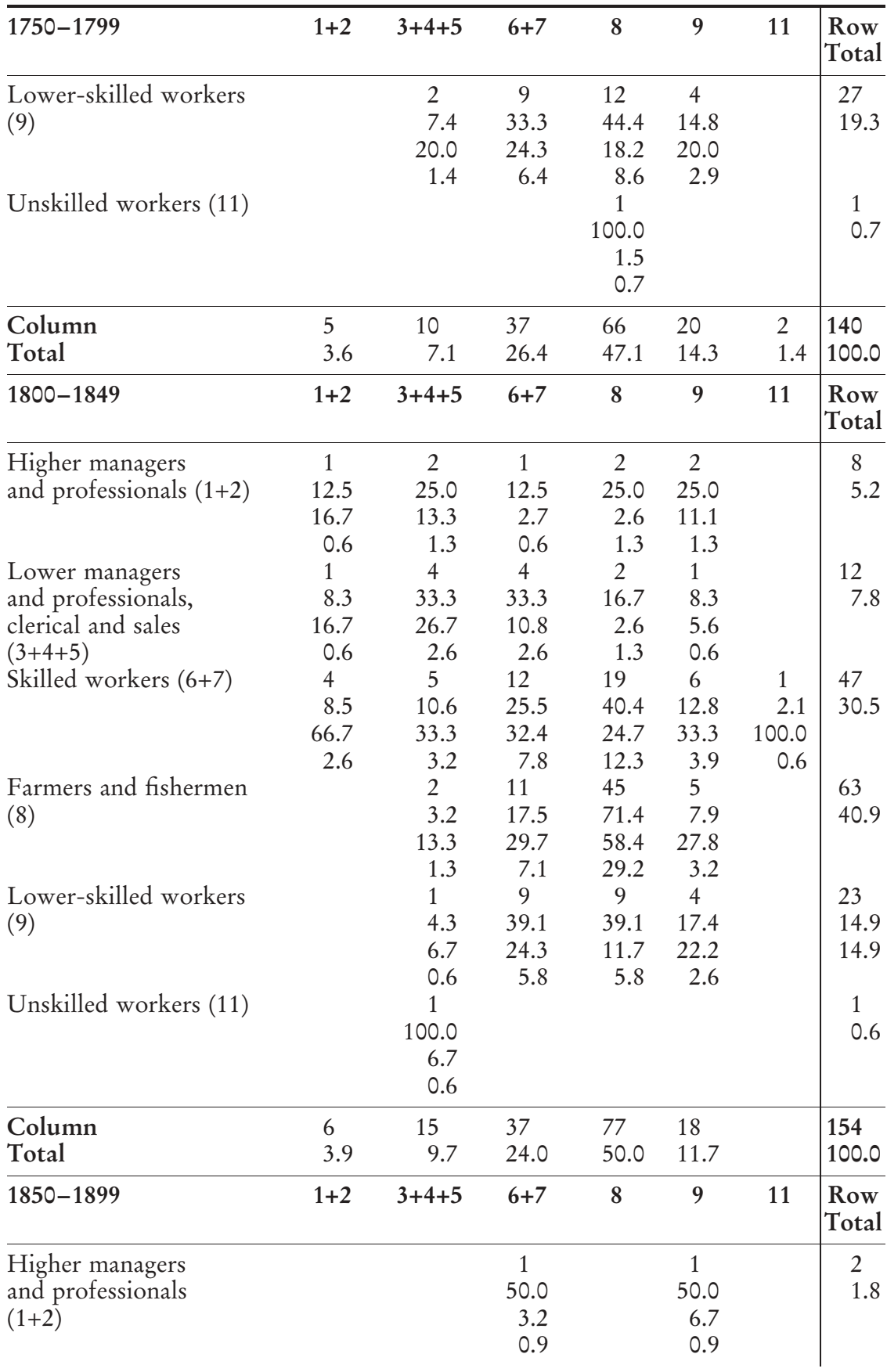

(Continued) 
Lower managers

and professionals,

clerical and sales

$(3+4+5)$

Skilled workers $(6+7)$

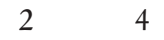

20.0

18.2

1.8

Farmers and fishermen

(8)

Lower-skilled workers

(9)

\begin{tabular}{ll} 
& \\
Column & \\
Total & \\
\hline
\end{tabular}

Value labels: I+2 higher mana professionals, clerical and sales, $6+7$ skilled workers, 8 farmers and fishermen, 9 lower-skilled workers, I I unskilled workers. Farm workers (IO+I2) existed only as servants, and they were not allowed to marry.

sons, daughters of skilled and lower-skilled workers more often married within the craft milieu than within the farming milieu: the proportion there is between Io per cent and 20 per cent, with the exception of the first half of the nineteenth century, when 29.7 per cent of marriages were between daughters of skilled workers and farmers' sons and 27.8 per cent of marriages were between daughters of lower-skilled workers and farmers'sons.

Among the fourth largest group, the lower managers and professionals, clerical and sales, which includes publicans and tradesmen (substantial portions of the local elite), skilled workers comprised the most important marriage circle aside from their own group. In the second half of the nineteenth century, however, their daughters' husbands came from the ranks of lower-skilled workers in four out of ten cases - another indication of social mobility.

It is apparent that the first half of the nineteenth century was the phase with most noticeable shifts. Aside from the political, social, and economic upheavals and the introduction of the marriage consensus, another circumstance which must be mentioned concerns the consequences of the wars and upheavals of the Napoleonic era of the late eighteenth and early nineteenth centuries. The second half of the nineteenth century seemed to show a tendency to level out, so to speak, at the status of the second half of the eighteenth century. These findings to some extent contradict the presumption that those changes led to shifts in the social 
status of occupational groups, which were presumed as well to be reflected in marriage alliances. That will be examined in a more detailed analysis.

The question also should be raised of whether the occupation of the groom should be included in the discussion of homogamy. If it is not, one will fail to take into consideration the social mobility between a man's origins and his own subsequent occupation, achieved by the time of his marriage (and that not least because of his late age at marriage). ${ }^{29}$ Was it a misalliance then when a day-labourer's son married the daughter of a publican? In the case of Josef Eisendle it was not, because although the son of a day-labourer, he had worked his way up to become a tradesman. ${ }^{30}$

It should be noted that not only was it possible to move up socially, there was also the risk of moving down, and for non-inheriting sons, for instance, that was a risk which increased especially in the nineteenth century. A drop in social status is not necessarily recognizable through occupational classification, however, because such men could certainly have learned a highly skilled trade. Detailed knowledge is needed of their actual working and property situations to be able to make a statement about their social status. If a man born to a lower-class family learned a skilled trade and married someone from a low-skilled or unskilled family, that would show up as homogamy rather than the downward marriage it arguably was in terms of current social status.

The particular question of social mobility illustrates that the links between individual occupational codes and generations and social status, being just collections of factors from more than one source and written registers, represent a leap to a different level qualitatively and so it is difficult to operationalize them. ${ }^{3 \mathrm{I}}$

\section{POINTS OF DISCUSSION AND DIFFERENT MEASURES FROM A LOCAL PERSPECTIVE}

Starting from the results of the evaluation based on HISCLASS, we have alluded to several points of discussion from a local perspective. These will be addressed in more detail in the following. For some of the points it

29. See for example Maria Carla Lamberti, "Immigrate e immigrati in una città preindustriale: Torino all'inizio dell'Ottocento", in Angiolina Arru and Franco Ramella (eds), L'Italia delle migrazioni interne. Donne, nomini, mobilità in età moderna e contemporanea (Rome, 2003), pp. I6I-205, 196.

30. Franz Eisendle moved to Innichen in the I 830 , and his father was listed as a day-labourer. Franz Eisendle worked in Innichen as a tradesman, had started with half a house rented with a colleague, married a publican's daughter, then owned first one half, later the other half also, of a house in the centre of town, subsequently held communal office, and eventually became mayor. 3I. Yet the inclusion of the property dimension is still insufficient to determine questions of social stratification. In this context, Giovanni Levi refers, for instance, to the complex family strategies that also have an impact on the question of social positioning. See Giovanni Levi, Das immaterielle Erbe. Eine bäuerliche Welt an der Schwelle zur Moderne (Berlin, 1986), p. 48. 
appears meaningful to focus additionally on several analyses modified specifically to take account of the local circumstances.

A first important point of discussion is the gender-specific difference in the extent of exchange between the crafts and the farming communities. That farmers' daughters frequently married into crafts households is probably due to the fact that virtually every trade and craft household had at least a small farm. It may be presumed that questions about the division of labour and the organization of work played a role in the choice of partner. In this form of mixed economy a relevant socialization of the wife in agriculture might have been more important than competence in the craft field, and in some sectors more than in others. The number of servants and the size of the agricultural property were factors to be taken into consideration, along with socio-cultural attitudes.

In fact, there were several sectors into which no farmers' daughters married, and some into which only a few married: among merchants, village barbers and surgeons, furriers, parchment makers, masons, and glazers there are no indications of connections in that direction. The proportion is just under or just over io per cent for first marriages among bakers, publicans, dyers, glove-makers, locksmiths, carpenters, and tailors, which suggests a stronger tendency among the middle sectors, primarily, to marry a woman from the farming milieu.

With respect to the marriage circles of farmers' sons, it should be noted that they did not necessarily become farmers themselves, for especially those who did not take over the farm often took different roads in life. In the evaluation it would be important therefore to start from the groom's occupation, not that of his father. That would allow a clearer insight into how important farming origins were for women who later became farmers.

In addition, in the Alpine context, it is worth making a distinction between farms in the valley and farms on mountain slopes. In Innichen, Innichberg ("Innich Hill"), located on the sunny side of the mountain, formed a separate municipality belonging to the same parish as the town but to a different court district. The Innichberg farms are found at an altitude of up to I,500 metres, but the fields and meadows belonging to them reach even higher. In terms of labour techniques and conditions, farm work on the mountain slope placed different demands on people from farm work in the valley. Mountain farmers or their children could settle in the valley, but valley farmers on the mountain?

Using reconstructed ownership successions for the twenty-eight Innichberger farms for the period I 700 to I 900 , we found only one farmer and town citizen who married up onto the mountain. ${ }^{32}$ He married a

32. The person in question was Johann Schett, who married the widow from the Burgmann Farm in 1746; BHM Lienz, OR III 4, Verfachbuch Heinfels 1737 III 22, fo. 372 and STA Innichen, Familienbuch 1700, fo. 625 . 
widow whose husband had been a mountain farmer. Due to the system of separate marital property, the widow could not take over the farm as an owner, so her seven-year-old son became the owner and her second husband, the town citizen, took the farm on a fifteen-year lease: that is, until the son came of age and could assume control himself. Almost 90 per cent of the Innichberger farmers came from Innichberg itself, the remaining Io per cent coming from outside to settle there. Did the choice of wives follow the logic of mountain-farmer origins just as strictly?

Several important parameters for classifying occupations according to the HISCLASS model could be added for the segment of crafts and trades to capture more accurately the complexity of Innichen's class structure, which was closely connected to the socio-political, socio-economic, and socio-cultural contexts outlined earlier. Certain categories of occupation were more highly regarded than others in Innichen, but that assessment did not necessarily run parallel to the distinction between the character of an occupation as skilled or lower-skilled. The social prestige of a craft apparently depended largely on the cost of the means of production required to carry out the profession, which ultimately meant property.

A tailor, for example, must have mastered the skills of his craft and was therefore a skilled worker according to HISCLASS, yet in terms of the preconditions for business he could just as well live and work somewhere as a lodger. Tanners require, in comparison, extensive equipment but they are ranked among the lower-skilled workers. Whereas tanning was often regarded as a less honourable craft in urban societies and banished to the outskirts of town or to remote streets because of the stench, it was one of the most prestigious guilds in Innichen. Marriage to a tanner or a tanner's son therefore tended to be linked with more social prestige in Innichen than marriage to a tailor or tailor's son. In the categorization of skilled and lower-skilled, however, that relation is exactly the reverse.

In addition, the status of being the only person in the town practising a craft which was important to local industry could also invest one with a special position. In Innichen this was true of the dyer's craft, for instance, which was passed on over generations in one highly respected family and was also one of the crafts requiring the most intensive means of production. HISCLASS, however, classifies dyers as lower-skilled workers.

Finally, the question should also be raised of the extent to which the importance and thus also attractiveness in the marriage market of certain occupations depended on their economic situation. A good test case from a local perspective would be that of the glove-maker. The manufacture of leather gloves flourished especially in the second half of the eighteenth century, and the number of glove-makers increased accordingly. ${ }^{33}$ 
Several of the discussion points mentioned here will be examined in more detail on the basis of individual occupational sectors or in groups somewhat different from those of HISCLASS, in an attempt to approximate the specific local scale of values in the town. In this scale of values, property is central, occupational skills are obviously subordinate to it.

\section{HOMOGAMY IN RELATION TO HUSBAND'S OCCUPATION}

The choice of partners from the perspective of the husbands' occupation compared with the perspective of the men's families of origin shows a tendency towards broader distribution at the level of individual occupations in the wife's family of origin, with the exception of glove-makers, cobblers, carpenters, and merchants. Differences are evident among mountain farmers, glove-makers, weavers, and publicans.

In comparison with the sons of mountain farmers in general, working mountain farmers largely married the daughters of other mountain farmers. It is highly probable that specific labour or technical requirements were a crucial factor in the choice of a wife. In dispensation applications for marriage among relatives, for example, there are references to the specific demands of the work of mountain farming, which were regarded as a factor making it more difficult to find a suitable spouse. ${ }^{34}$ Yet thirteen daughters of market citizens married someone from Innichberg, of whom eight married into farms at a slightly lower level, while three married widowers, whose farms were among the more prosperous ones with several servants. The women mostly came from long-established farming families in the town. ${ }^{35}$ It is evident especially in the nineteenth century that between 50 and 70 per cent of women who married in Innichberg were themselves from mountain-farming families. ${ }^{36}$

Glove-makers generally married farmers' daughters less often than did their sons. In this activity, which in Innichen emerged and flourished over

fourteen journeymen and apprentices, thirty-nine male and female helpers. See Bibliothek des Stiftes Innichen, Urkundenbuch, MS VIII, b 6, fo. 37 ff., cit. from Rogger, "Handwerker und Gewerbetreibende”, p. 20.

34. An applicant for a marriage dispensation explained, for example, that "not everyone can be got up on the mountain, and not everyone can be used either"; Diözesanarchiv Brixen, Konsistorialakten I 874, Fasz. 22A, Römische Ehedispensen, no. I 5 ; see also the article by Hilde Bras and Jan Kok in this volume, pp. 247-274.

35. Multiple ties of marriage between the town and the mountain could be reconstructed for a family of market farmers, the Kohlschneider Farm, which ran in both directions with a certain regularity. See STA Innichen, Familienbuch I700, fos I4, 279, 283, 499, 760.

36. There is also a problem here with the high proportion of women marrying in from outside, because without specific knowledge of the area it is not possible to determine whether they came from the valley or the mountain. For this reason, these data represent minimum percentages; the actual percentages are probably higher. 
the course of the eighteenth century, the social status of glove-makers and their children appears to have diverged, which could indicate a somewhat ambivalent in-between position. For the spectrum of families of origin whose daughters married a glove-maker is very broad, and ranges into the higher crafts and trades, 37 but, conversely, not a single glove-maker's daughter appears as a wife among the more prestigious sectors in the sample. The marriage relationships thus remained one-sided here.

Compared with their sons, weavers were more likely to have married the daughters of other weavers or - in the nineteenth century - the daughters of valley farmers, and since weaving was often practised as a secondary occupation to farming there was more scope for the marriage circles to overlap in these cases. ${ }^{8}$ Weavers also married the daughters of bakers, millers, and tanners, but, most frequently, among the craft and trade branches, and unlike smiths or shoemakers for example, they married women from the same branch.

Among publicans, it is particularly noticeable that in the second half of the nineteenth century there was a broader distribution in the selection of partners among publicans' sons than among publicans. Among craftsmen and tradesmen, publicans show the highest proportion of occupational endogamy: 39 heirs and purchasers of public houses tended to marry publicans' daughters. In Innichen, publicans were simultaneously the owners of the largest farms, evident, for instance, in the number of maids and male servants working there - and so publicans were among the local elite. Here, it is relatively clear that occupational endogamy can be regarded as social homogamy too.

Relevant socialization among women and their familiarity with its demands was obviously an advantage, especially in the sectors where they contributed their labour, which was specifically sought, as was the case with wives of mountain farmers and publicans alike. Occupational endogamy and social homogamy coincided most clearly in those sectors.

\section{DIFFERENTLY GROUPED}

The social stratification of a local society depends to a certain degree on a specific system of values changing over time. From a micro-historical perspective, the central aim is to ascertain the elements of the prevailing system of values and to reconstruct their implications for the social profile

37. The situation was different among shoemakers and cobblers for example - other crafts that were widespread locally - the more prestigious spheres are hardly present; one baker's daughter and one smith's daughter are the exception.

38. A problem that cannot be addressed in greater depth here is that multiple professions and occupations can change the social profile of individual professions.

39. The marriage circle for commercial and merchant professions was similarly specific: here the marriage circle included daughters of tradespeople augmented by apothecaries and civil servants. 
of a community. If this interconnection is a crucial point of the investigation, then the social classification too should be orientated by its values and implications.

To clarify the particular situation in Innichen in the second half of the nineteenth century, occupations are here grouped together in a social matrix constructed by the author to reflect detailed knowledge of social relationships among certain occupational groups from which the examples in the section above were taken, and to reflect the means of production required by craftsmen. We have in group I: bakers, publicans, merchants forming the local elite; ${ }^{\circ}$ group 2: high-level crafts requiring a sizeable means of production; ${ }^{41}$ group 3: farmers; group 4: mid-level crafts between groups 2 and 5 in terms of means of production; group 5: mass crafts requiring comparatively little in the way of means of production and carried out by comparatively many people in the town; group 6: various functions and offices (such as barber-surgeons, imperial and royal hunters, local court clerks, district court "commissars", and sextons); group 7: other.

Calculated in 50-year increments (Table 2 overleaf), sons of bakers, publicans, and merchants in group I married within their own group less and less often (from 66.7 per cent to 28.6 per cent). In the nineteenth century there was initially a shift towards the farmers, followed by a shift back towards the high-level crafts in the second half of the nineteenth century. This reversion could indicate that those sectors, which were among the most property-intensive, had meanwhile consolidated or reorientated in a better way; agriculture especially gained in importance in this context..$^{22}$ It is interesting here that the category "other", which ranked third in this period, is an expression of the tendency to change revealing a habit of marrying downward if one examines actual cases. Of course, this conclusion is based on a very small group, but every single case counts in the sense of the scope of options for action.

Among daughters from this first group (Table 3 overleaf) the preferred sectors of origin remained more consistent. For the second half of the nineteenth century this evaluation confirms the HISCLASS conclusion of downward marriage, with daughters from group I marrying sons from

40. Bakers also had a licence to run a public house. The local publicans had the largest farms and the highest number of servants. From inventories and various contracts one finds a high level of property and/or means among this group of bakers, publicans, and merchants. They are addressed as "Herr" in contracts, registers and so on. They were very often engaged in communal functions, as mayors, as communal representatives, as administrators of communal funds (for the poor and orphans, for example) and they were also frequently engaged as guardians for minors after a father's death.

4I. The results of the reconstruction of property transfers also indicate that special sectors are involved here: in these sectors there was a greater continuity of property and profession between fathers and sons or sons-in-law. See Lanzinger, Das gesicherte Erbe, pp. $234 \mathrm{ff}$.

42. For example, a master tanner opened a tavern in this period. 
Table 2. Occupation of father of the groom (row) by that of father of the bride (column), first marriage of groom in \%

\begin{tabular}{|c|c|c|c|c|c|c|c|c|}
\hline & 1 & 2 & 3 & 4 & 5 & 6 & 8 & Total \\
\hline $\begin{array}{l}1700-1749 \\
1 \text { Bakers, publicans, } \\
\text { merchants }\end{array}$ & 66.7 & 11.1 & 11.1 & 11.1 & & & & 9 \\
\hline 2 High-level crafts* & 23.1 & 30.8 & 15.4 & 15.4 & 15.4 & & & 13 \\
\hline 3 Farmers & 4.0 & 12.0 & 68.0 & 12.0 & & & 4.0 & 25 \\
\hline 4 Mid-level crafts ${ }^{* *}$ & 10.0 & 20.0 & & 20.0 & 40.0 & 10.0 & & 10 \\
\hline 5 Mass crafts ${ }^{* * *}$ & & 15.4 & 30.8 & 7.7 & 38.5 & & 7.7 & 13 \\
\hline $\begin{array}{l}6 \text { Various functions } \\
\text { and offices } \\
7 \text { Other }\end{array}$ & & 100.0 & & & & & & 1 \\
\hline Total & & & & & & & & 71 \\
\hline $\begin{array}{l}1750-1799 \\
1 \text { Bakers, publicans, } \\
\text { merchants }\end{array}$ & 57.1 & 28.6 & & & 14.3 & & & 7 \\
\hline 2 High-level crafts* & 10.5 & 26.3 & 42.1 & 15.8 & 5.3 & & & 19 \\
\hline 3 Farmers & & 7.1 & 83.3 & 2.4 & 2.4 & 2.4 & 2.4 & 42 \\
\hline 4 Mid-level crafts** & 5.6 & 22.2 & 27.8 & 11.1 & 16.7 & 11.1 & 5.6 & 18 \\
\hline 5 Mass crafts ${ }^{* * *}$ & 2.7 & 8.1 & 35.1 & 16.2 & 29.7 & 8.1 & & 37 \\
\hline $\begin{array}{l}6 \text { Various functions } \\
\text { and offices }\end{array}$ & 7.1 & & & 14.3 & 35.7 & 28.6 & 14.3 & 14 \\
\hline 7 Other & & & 66.7 & 33.3 & & & & 3 \\
\hline Total & & & & & & & & 140 \\
\hline $\begin{array}{l}1800-1849 \\
1 \text { Bakers, publicans, } \\
\text { merchants }\end{array}$ & 46.2 & 7.7 & 23.1 & & 7.7 & 7.7 & 7.7 & 13 \\
\hline 2 High-level crafts* & 10.5 & 21.1 & 42.1 & & 21.1 & 5.3 & & 19 \\
\hline 3 Farmers & 1.6 & 3.2 & 71.4 & 7.9 & 12.7 & 1.6 & 1.6 & 63 \\
\hline 4 Mid-level crafts** & 3.6 & 14.3 & 39.3 & 25.0 & 7.1 & 7.1 & 3.6 & 28 \\
\hline 5 Mass crafts*** & 4.5 & 4.5 & 36.4 & 9.1 & 31.8 & 4.5 & 9.1 & 22 \\
\hline $\begin{array}{l}6 \text { Various functions } \\
\text { and offices }\end{array}$ & 16.7 & & & 50.0 & 16.7 & 16.7 & & 6 \\
\hline 7 Other & 33.3 & & & & 33.3 & & 33.3 & 3 \\
\hline Total & & & & & & & & 154 \\
\hline $\begin{array}{l}1850-1899 \\
1 \text { Bakers, publicans, } \\
\text { merchants }\end{array}$ & 28.6 & 35.7 & 7.1 & & & & 28.6 & 14 \\
\hline 2 High-level crafts* & 22.2 & 11.1 & 33.3 & 5.6 & 11.1 & & 16.7 & 18 \\
\hline 3 Farmers & 2.4 & 2.4 & 80.5 & 4.9 & 4.9 & 2.4 & 2.4 & 41 \\
\hline 4 Mid-level crafts** & & 12.5 & 25.0 & 12.5 & 37.5 & 6.3 & 6.3 & 16 \\
\hline 5 Mass crafts ${ }^{* * *}$ & 10.5 & & 15.8 & 31.6 & 26.3 & 5.3 & 10.5 & 19 \\
\hline $\begin{array}{l}6 \text { Various functions } \\
\text { and offices }\end{array}$ & & 100.0 & & & & & & 1 \\
\hline 7 Other & & & & 50.0 & 50.0 & & & 2 \\
\hline Total & & & & & & & & 111 \\
\hline
\end{tabular}

* Butchers, millers, tanners, dyers, smiths, glazers, and hat makers.

** All other crafts.

*** Tailors, cobblers, glove-makers, and weavers. 
Table 3. Occupation of father of the bride (row) by that of father of the groom (column), first marriage of groom in \%

\begin{tabular}{|c|c|c|c|c|c|c|c|c|}
\hline & 1 & 2 & 3 & 4 & 5 & 6 & 8 & Total \\
\hline $\begin{array}{l}1700-1749 \\
1 \text { Bakers, publicans, } \\
\text { merchants }\end{array}$ & 54.5 & 27.3 & 9.1 & 9.1 & & & & 11 \\
\hline 2 High-level crafts* & 7.7 & 30.8 & 23.1 & 15.4 & 15.4 & 7.7 & & 13 \\
\hline 3 Farmers & 4.2 & 8.3 & 70.8 & & 16.7 & & & 24 \\
\hline 4 Mid-level crafts** & 11.1 & 22.2 & 33.3 & 22.2 & 11.1 & & & 9 \\
\hline 5 Mass crafts ${ }^{* * *}$ & & 18.2 & & 36.4 & 45.5 & & & 11 \\
\hline $\begin{array}{l}6 \text { Various functions } \\
\text { and offices }\end{array}$ & & & & 100.0 & & & & 1 \\
\hline 7 Other & & & 50.0 & & 50.0 & & & 2 \\
\hline Total & & & & & & & & 71 \\
\hline $\begin{array}{l}\text { 1750-1799 } \\
1 \text { Bakers, publicans, } \\
\text { merchants }\end{array}$ & 44.4 & 22.2 & & 11.1 & 11.1 & 11.1 & & 9 \\
\hline 2 High-level crafts* & 11.8 & 29.4 & 17.6 & 23.5 & 17.6 & & & 17 \\
\hline 3 Farmers & & 12.7 & 55.6 & 7.9 & 20.6 & & 3.2 & 63 \\
\hline 4 Mid-level crafts** & & 20.0 & 6.7 & 13.3 & 40.0 & 13.3 & 6.7 & 15 \\
\hline 5 Mass crafts ${ }^{* * *}$ & 4.5 & 4.5 & 4.5 & 13.6 & 50.0 & 22.7 & & 22 \\
\hline $\begin{array}{l}6 \text { Various functions } \\
\text { and offices }\end{array}$ & & & 10.0 & 20.0 & 30.0 & 40.0 & & 10 \\
\hline 7 Other & & & 25.0 & 25.0 & & 50.0 & & 4 \\
\hline Total & & & & & & & & 140 \\
\hline $\begin{array}{l}1800-1849 \\
1 \text { Bakers, publicans, } \\
\text { merchants }\end{array}$ & 46.2 & 15.4 & 7.7 & 7.7 & 7.7 & 7.7 & 7.7 & 13 \\
\hline 2 High-level crafts* & 8.3 & 33.3 & 16.7 & 33.3 & 8.3 & & & 12 \\
\hline 3 Farmers & 4.0 & 10.7 & 60.0 & 14.7 & 10.7 & & & 75 \\
\hline 4 Mid-level crafts** & & & 29.4 & 41.2 & 11.8 & 17.6 & & 17 \\
\hline 5 Mass crafts*** & 4.2 & 16.7 & 33.3 & 8.3 & 29.2 & 4.2 & 4.2 & 24 \\
\hline $\begin{array}{l}6 \text { Various functions } \\
\text { and offices }\end{array}$ & 14.3 & 14.3 & 14.3 & 28.6 & 14.3 & 14.3 & & 7 \\
\hline 7 Other & 16.7 & & 16.7 & 16.7 & 33.3 & & 16.7 & 6 \\
\hline Total & & & & & & & & 154 \\
\hline $\begin{array}{l}1850-1899 \\
1 \text { Bakers, publicans, } \\
\text { merchants }\end{array}$ & 36.4 & 36.4 & 9.1 & & 18.2 & & & 11 \\
\hline 2 High-level crafts* & 45.5 & 18.2 & 9.1 & 18.2 & & 9.1 & & 11 \\
\hline 3 Farmers & 2.1 & 12.8 & 70.2 & 8.5 & 6.4 & & & 47 \\
\hline 4 Mid-level crafts** & & 8.3 & 16.7 & 16.7 & 50.0 & & 8.3 & 12 \\
\hline 5 Mass crafts*** & & 12.5 & 12.5 & 37.5 & 31.3 & & 6.3 & 16 \\
\hline $\begin{array}{l}6 \text { Various functions } \\
\text { and offices }\end{array}$ & & & 33.3 & 33.3 & 33.3 & & & 3 \\
\hline 7 Other & 36.4 & 27.3 & 9.1 & 9.1 & 18.2 & & & 11 \\
\hline Total & & & & & & & & 111 \\
\hline
\end{tabular}

* Butchers, millers, tanners, dyers, smiths, glazers, and hat makers.

** All other crafts.

*** Tailors, cobblers, glove-makers, and weavers. 
group 5 (mass crafts). ${ }^{43}$ In group 2 (tanners, dyers, smiths, glazers, etc.) the emphasis shifted from the same group, which was dominant in the first half of the eighteenth century, to farmers between 1750 and I 850 . In the second half of the nineteenth century the spectrum of marriage circles became considerably more dispersed.

It is an indication of the strong position of the farming community in the second half of the nineteenth century that the rate remained high at 80.5 per cent for marriages between sons from farming families and daughters likewise from farming families (Table 2). Similarly, in the second half of the nineteenth century (1850-1899) and also in the first half of the eighteenth century (I700-I749) just over 70 per cent of farmers' daughters married within their own group (Table 3 ).

Access to marriage circles among farmers became less assured for the broad range of craftsmen in group 4 : in the nineteenth century they initially married most frequently within their own group, and from the group of mass crafts in the second half of the nineteenth century. The situation for group 5 was similar: in the second half of the nineteenth century there were few marriages between men in group 5 and daughters of farmers; sons of tailors, cobblers, glove-makers, and weavers mostly married daughters from the mid-level crafts group. The order of the origins of marriage partners for daughters from group 5 was similar during that period.

\section{CONCLUSION}

The analyses based on occupational groups classified according to the international, HISCLASS scheme and based on the author's own scheme of occupational groups orientated towards local criteria correspond in terms of gender-specific differences in marriage preferences particularly between craftsmen and farmers: craftsmen's daughters married much less often into the farming community than farmers' daughters into the crafts community. That could support the theory that choice of partner involved not only status, but matters of socialization and labour requirements. Wives or daughters could play a role in the formation of alliances following a logic different from that governing the marriages of sons, conspicuously so for instance in the group of high-level crafts in the second half of the nineteenth century, where the marriage circles of daughters differed considerably from those of sons.

The impact of changes to the local system of values caused by socio-

43. In the light of the comparatively limited marriage opportunities, the question also arises as to whether in some cases prestige was not also expressed by more than one child being able to marry in the town. Perhaps this sometimes relativized the idea of homogamy and made it seem less important. 
economic factors, which meant especially the unprofitability of numerous crafts that produced for a translocal market in the nineteenth century due to industrial competition, is clearly evident in the shifts in marriage circles between occupational groups. ${ }^{44}$ This affords an even greater significance to property in comparison with crafts skills for instance. It was a development leading to a better position for farmers and helped the craftsmen possessing more property to achieve a certain consolidation or greater opportunities for reorientation. A degree of re-agrarianization can be noted in the second half of the nineteenth century. However, the property criterion seems to have outweighed everything else.

That might also be why this specific situation emerges less markedly using the HISCLASS scheme than it does using a local social matrix: whereas in the second half of the nineteenth century patterns are seen to deviate from earlier periods in several respects if we use a categorization relating to the local context, with the HISCLASS scheme the manifestations of change are shifted more towards the first half of the nineteenth century. From a micro-historical perspective focusing on Innichen, there is thus a need to introduce additional parameters coupled with spatialtemporal specifics into the link between occupational endogamy and social homogamy. ${ }^{45}$ Arguably then, one should allow the open and variable formation of groups for these kinds of evaluation, since this would allow for the necessary differentiations and shifts in emphasis, albeit perhaps at the expense of comparability.

The central question is whether the socio-political context outlined in the beginning affected partner selection in the direction of a preference for homogamy. In the light of the actively and purposely pursued policy of social stability at the communal level, did a marriage "among equals" represent a further stabilizing factor? To a certain degree, a tendency of the kind can be presumed. In particular, shifts in the marriage circles in both the first and the second halves of the nineteenth century can be regarded as a consequence of new endeavours to compensate for changes in status due to economic and social upheavals. When social parameters were shifted, the choice of partner followed suit, although it took some time for it to become clear which course the new positionings would take.

44. Samples of community and court representatives (up to I 806) show a change between the late seventeenth and late eighteenth centuries from a composition comprising publicans especially to one reflecting a much broader base of craftsmen. Craftsmen were clearly less represented in the I86os, when merchants and publicans too made up half of the community council. Although farmers were not more numerously represented here than before, in the late nineteenth century they increasingly took over communal offices held previously by all heads of households for one or two years at a time under a rotation system. See Lanzinger, Das gesicherte Erbe, pp. Ios ff.

45. See for example Detlev Mares, "Abschied vom Klassenbegriff? Viktorianische Arbeiterbewegung, politische Sozialgeschichte und linguistic turn in England", Nene Politische Literatur, 42 (1997), pp. 378-394. 
It has also become clear that property defined social status. ${ }^{46}$ The choice of partner also proved to have a stabilizing effect to the extent that its circles could only be expanded within a limited range - as is evident, for example, in the one-sided bands of marriage under flourishing conditions between women of a higher social position and glove-makers: there was no corresponding upward reciprocity in the next generation.

Strategies, but opportunities too, were different for the separate sectors, forming a bottleneck from top to bottom. That is especially evident in the case of farmers' daughters, who were increasingly acceptable to higher branches in the course of a re-evaluation of agriculture, but who were less often present in the less attractive segments of mid-level and mass crafts. Despite a strong orientation towards property, there were cases of downward marriages again and again - as shown particularly among the elite group of bakers, publicans and merchants. This relativization of homogamy should also quite probably be seen against the background of restrictive marriage policies. 